\title{
ASPEK-ASPEK YURIDIS DALAM SALVAGE \\ (PENYELAMATAN KECELAKAAN KAPAL)
}

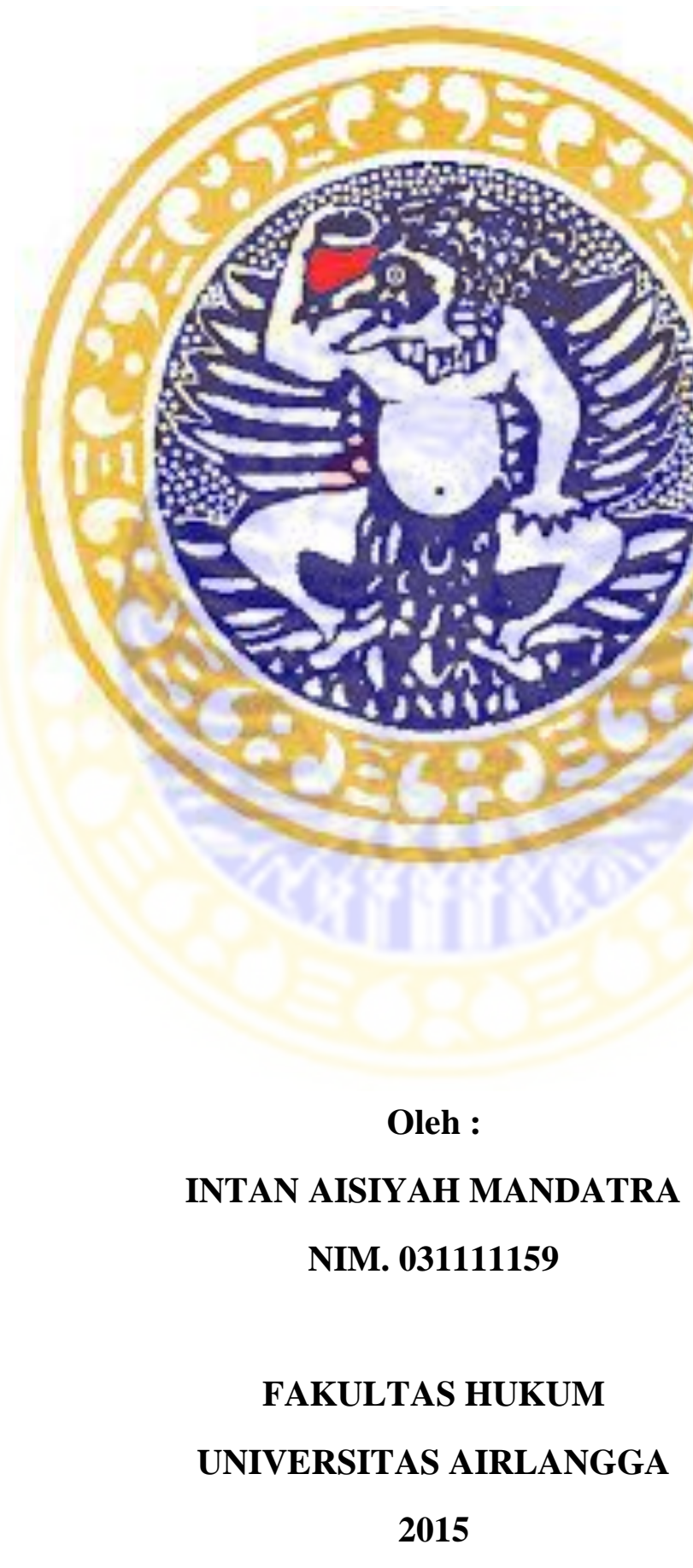




\title{
SKRIPSI
}

\author{
ASPEK - ASPEK YURIDIS DALAM SALVAGE \\ (PENYELAMATAN KECELAKAAN KAPAL)
}

INTAN A MANDATRA

031111159

FAKULTAS HUKUM

UNIVERSITAS AIRLANGGA

2015 


\section{ASPEK - ASPEK YURIDIS DALAM SALVAGE \\ (PENYELAMATAN KECELAKAAN KAPAL)}

SKRIPSI

Diajukan Untuk Melengkapi Tugas dan Memenuhi Syarat Untuk Mencapai Gelar Sarjana Hukum

DOSEN PEMBIMBING

Koesrianti, S.H., LL.M., Ph.D

NIP. 196209081987012001
PENYUSUN

Intan A Mandatra

NIM. 031111159

FAKULTAS HUKUM

UNIVERSITAS AIRLANGGA

2015

ii 
Skripsi ini telah diuji dan dipertahankan di hadapan Tim Penguji Pada Tanggal 06 Januari 2015

Tim Penguji Skripsi:

Ketua : Dr. Zahry Vandawati Chumaida, S.H., M.H.

Anggota : 1. Koesrianti, S.H., LL.M., Ph.D.

2. Dr. Aktieva Tri Tjitrawati, S.H., M.Hum.

3. Dian P Anugerah., S.H., M.Kn., LL.M. 


\section{Mothing is impossible, the ward itself says "I"mpassiblel"}

-Audrey Hepburn- 


\section{KATA PENGANTAR}

Segala puja dan puji syukur penulis panjatkan kepada kehadirat Allah SWT atas berkat dan rahmat-Nya penulis dapat menyelesaikan skripsi yang berjudul “ASPEK - ASPEK YURIDIS DALAM SALVAGE (PENYELAMATAN KECELAKAAN KAPAL)" dengan lancar tanpa halangan yang berarti. Skripsi ini merupakan syarat kelulusan untuk memperoleh gelar kesarjanaan dalam Ilmu Hukum pada Fakultas Hukum Universitas Airlangga.

Begitu banyak hal bermanfaat yang penulis dapatkan selama pengerjaan skripsi ini, dengan segala kesabaran dan kepercayaan bahwa penulisan skripsi ini dapat diselesaikan dengan baik dan memberikan manfaat kepada pihak-pihak yang ingin mengetahui mengenai aspek-aspek apa yang terdapat dalam salvage serta penerapannya di Indonesia sebagaimana yang tertuang dalam skripsi ini.

Dalam kesempatan ini, dengan kerendahan hati saya hendak mengucapkan terima kasih kepada para pihak yang telah banyak memberikan bantuan, bimbingan, serta dukungannya guna terwujudnya penulisan skripsi ini. Maka pada kesempatan ini, saya ingin menyampaikan penghargaan dan ucapan terima kasih yang sebesar-besarnya kepada :

1. Prof. Dr. Muchammad Zaidun, S.H., M.Si selaku Dekan Fakultas Hukum Universitas Airlangga.

2. Koesrianti, S.H., LL.M., Ph.D. selaku dosen pembimbing yang telah memberikan bimbingan sekaligus arahan, saran, serta waktu sehingga skripsi ini dapat terselesaikan dengan baik dan tepat pada waktunya. 
3. Dr. Zahry Vandawati Chumaida, S.H., M.H., Koesrianti, S.H., LL.M., Ph.D., Dr. Aktieva Tjitrawati, S.H., M.Hum., dan Dian Purnama Anugerah, S.H., M.Kn., LL.M. yang telah menguji, memberikan penjelasan, masukan dan nasihat terkait penulisan skripsi ini.

4. Deddy Sutrisno, S.H., M.H. selaku dosen wali yang membimbing selama proses penyusunan mata kuliah.

5. Seluruh Dosen dan Tim Pengajar di Fakultas Hukum Universitas Airlangga.

6. Kedua orangtua penulis Rumanto dan Enni Tjitrakoesoema atas segala doa, dukungan, dan didikan yang selalu diberikan kepada penulis, adik tersayang Muhammad Ilham Mandatra serta keluarga besar penulis atas support dan doanya selama ini.

7. Saudara-saudara Modus tercinta : Adinda Balung, Kristin, Ibeth, Irma Cece, Bang Dharaf, Alfian, Fitrah Smith, Yudha, Alan, Irul, Reza,Yudhis dan Chazmil.

8. KKN BBM 51 Sukorejo : Rindu, Seli, Shinta, Anis, Shanti, Fia, Alifia, Vidi, Alfafa, dan Samuel

9. Seluruh mahasiswa Fakultas Hukum Universitas Airlangga angkatan 2011, minat Bisnis dan minat Internasional.

10. BPH ALSA LC UNAIR periode 2014 - 2015 : Aryo, Dharaf, Kemal, Nisden, Irma, Rr. Adinda, Elisabeth, Ella, Esti, Yoyok, Yudhis, Yudha, Alan, dan Novita 
11. Seluruh Alumni ALSA teman-teman ALSA, serta adik-adik angkatan, ALSA, yang memberi banyak inspirasi juga dukungan kepada penulis

12. Teman-teman PLKH A2-3 : Tegar, Dinda, Hannifa, Iqbal, Radit, Hanif, Hanief, Cicin, Ashari, Bima, Taajul, Edwin, Putri, Okky dan Muas

13. Teman Suka-suka tersayang : Dina, Riska, Ditha, dan Firly serta Pipit juga Karin

14. Teman-teman Law Choir, Shofa, Tiwi, R. Reza. Lita, Mishbah, Karina, dkk; Ilusivo; PSUA dan YourRaisa

15. Musik-musik Michael Buble, Raisa, Tulus, Trio Lestari, Adele, India Arie, Maroon 5, Coldplay, Bossanova Jawa, dan Pentatonix

16. Semua pihak yang turut membantu dan memberikan dukungan dalam penulisan skripsi ini, yang tidak dapat penulis sebutkan satu persatu.

Penulis menyadari bahwa masih banyak terdapat kekurangan dalam skripsi ini, sehingga dengan segala kerendahan hati penulis masih mengharapkan saran dan kritik yang membangun dari rekan-rekan pembaca.

Surabaya, 06 Januari 2015

Penulis,

Intan A Mandatra

NIM. 031111159 